\title{
Mitochondrial DNA corroborates the species distinctiveness of the Planalto (Thamnophilus pelzelni Hellmayr, 1924) and the Sooretama (T. ambiguus Swainson, 1825) Slaty-antshrikes (Passeriformes: Thamnophilidae)
}

\author{
Lacerda, DR. ${ }^{\mathrm{a}}$, Marini, MA. ${ }^{\mathrm{a}, \mathrm{b}}$ and Santos, FR. ${ }^{\mathrm{a}}{ }^{\mathrm{w}}$ \\ aDepartamento de Biologia Geral, Instituto de Ciências Biológicas, Universidade Federal de Minas Gerais, \\ CP 486, CEP 31270-901, Belo Horizonte, MG, Brazil \\ ${ }^{\text {b}}$ Departamento de Zoologia, Instituto de Biologia, Universidade de Brasília, \\ CEP 70910-900, Brasília, DF, Brazil \\ *e-mail: fsantos@icb.ufmg.br
}

Received May 31, 2007 - Accepted October 3, 2007 - Distributed December 1, 2007

(With 2 figures)

\begin{abstract}
The Thamnophilus punctatus complex has been recently reviewed on the basis of morphological and vocal characters, and is divided in six different species. Two of the new species, although well defined on the basis of morphological differences, could not be unambiguously distinguished through their loudsongs. The Planalto Slaty-antshrike (Thamnophilus pelzelni) and the Sooretama Slaty-antshrike (T. ambiguus) are most easily distinguished by subtle and localized changes in plumage colors of males and females. In the present study we used sequences of the control region, Cytochrome b, and ND2 genes, of the mitochondrial DNA (mtDNA) to evaluate the levels of molecular differentiation between these two species. The mean pairwise distance between the two species was $3.8 \%$, while it varied from $2.7 \%$ to $4.9 \%$ for each mtDNA region. Although extensive variation was also detected among haplotypes within species, especially for T. ambiguus, we suggest that the genetic divergence found between T. ambiguus and T. pelzelni is high enough to corroborate the separate species status of these two antbird taxa.
\end{abstract}

Keywords: antbirds, mitochondrial DNA, molecular differentiation, aves, Thamnophilidae.

\section{DNA mitocondrial corrobora a distinção entre as espécies Thamnophilus pelzelni Hellmayr, 1924 e T. ambiguus Swainson, 1825 (Passeriformes: Thamnophilidae)}

\begin{abstract}
Resumo
O complexo Thamnophilus punctatus foi recentemente revisado, com base em caracteres morfológicos e vocais, sendo dividido em seis diferentes espécies. Duas dessas novas espécies, embora bem definidas com base em distinções morfológicas, não puderam ser definitivamente diferenciadas por seus cantos. Thamnophilus pelzelni (choca-do-planalto) e T. ambiguus (choca-de-sooretama) são mais facilmente diferenciadas por sutis e localizadas mudanças de coloração da plumagem de machos e fêmeas. Neste estudo, foram utilizadas seqüências de DNA mitocondrial (região controle, Citocromo b e ND2) a fim de avaliar os níveis de diferenciação molecular entre estas duas espécies. A divergência genética média entre as duas espécies foi de $3,8 \%$, enquanto para cada região mitocondrial esta variou entre $2,7 \%$ e 4,9\%. Embora tenha sido observada grande variabilidade entre haplótipos dentro das espécies, especialmente para $T$. ambiguus, os resultados sugerem que a divergência genética observada entre T. ambiguus e T. pelzelni é suficientemente elevada para corroborar o status de espécies separadas destes dois Thamnophilidae.
\end{abstract}

Palavras-chave: papa-formigas, DNA mitocondrial, diferenciação molecular, aves, Thamnophilidae.

\section{Introduction}

In 1997, Isler and colleagues have proposed the division of Thamnophilus punctatus complex in six different species. Their study was based on vocalization, geographic distribution, plumage, and some other morphological characters to distinguish the different species of the complex (Isler et al., 1997). According to these authors, the Planalto Slaty-antshrike (Thamnophilus pelzelni Hellmayr, 1924) and the Sooretama Slatyantshrike (Thamonophilus ambiguus Swainson, 1825) share several morphological features and are most easily distinguished by plumage colors. The underpart of T. pelzelni males is gray with the center of the belly extensively whitish, while in T. ambiguus males, the underpart is also gray but with whitish on the belly ab- 
sent or confined to spots or bars. The color of the upper back of females is also an important marker: it is brown to reddish-brown for $T$. pelzelni and olive-brown for T. ambiguus. Morphological measures indicate that the bill tends to be smaller in T. pelzelni than in T. ambiguus, as well as the tarsus, tail, and wings, although these morphological characters overlap considerably (Isler et al., 1997). Furthermore, T. pelzelni presents variable plumage coloration and more detailed studies are still needed to understand the geographic variation of this species (Isler et al., 1997). Zimmer (1933) had reported that individuals, corresponding today to T. ambiguus and $T$. pelzelni, intergrade in eastern Bahia State, Brazil, and Isler et al. (1997) stated that they seem to be parapatric in Bahia, with T. ambiguus occurring in the coastal plain and T. pelzelni in the adjacent uplands. The lack of clinal intermediacy in their contact zone (Naumburg, 1937; Isler et al., 1997) reinforces their species status. However, although loudsongs of T. ambiguus and T. pelzelni are almost always identifiable, Isler et al. (1997) could not use them to distinguish unambiguously these two taxa since they found overlapping characteristics.

Thamnophiluspelzelni occurs in several Brazilian states such as Maranhão, Piauí, Ceará, Paraíba, Pernambuco, Alagoas, Sergipe, Bahia, Goiás, Mato Grosso, Mato Grosso do Sul, São Paulo, and Minas Gerais (Isler et al., 1997). This species occupies the under- and mid-story of deciduous and semi-deciduous forests. In the south and west of its distribution, this species occurs mainly in gallery forests (Zimmer and Isler, 2003). It can be found up to $400-800 \mathrm{~m}$ a.s.l. (above sea level) in the northeast and as high as 1,100 m a.s.l. in the Central Brazilian Planalto (Isler et al., 1997). Although T. pelzelni is found in two extremely endangered Brazilian biomes (the Cerrado and the Atlantic Forest), it is not threatened by extinction, occurring at large densities in the north of its distribution (Zimmer and Isler, 2003).

Thamnophilus ambiguus is endemic to southeast Brazil, occurring mainly near the coast but also extending inland in southeast (Isler et al., 1997) and northeast (M. Marini, unpublished data) of Minas Gerais State. This species can be found from southern Sergipe to Rio de Janeiro. Thamnophilus ambiguus occupies the underand mid-story of lowland evergreen forest edge, woodland growing in coastal belt, and second growth near woodland to $700 \mathrm{~m}$ a.s.l. (Zimmer and Isler, 2003). It is frequently found in the forest edge and light-gaps in the forest interior (Zimmer and Isler, 2003), and commonly observed in its area of occurrence.

A consistent species definition is a fundamental basis for research in the fields of systematic, zoogeography, ecology and, conservation (Isler et al., 1998). It gains more importance if the species definition involves taxa endemic to endangered biomes, like the Brazilian Atlantic Forest. In other words, it is important to corroborate the species status of T. ambiguus, as well as its area of occurrence, since its endemicity to the southeast region of Brazil may have to be considered when conser- vation efforts focusing on bird populations are directed to this region. It is worth mentioning that the Atlantic Forest is one of the five hottest hotspots for conservation priorities in the world (Myers et al., 2000) as well as one of the four hotsposts of threatened avian diversity in the Neotropics (Stotz et al., 1996).

Recently, Brumfield and Edwards (2007) conducted a broad study focusing on the evolution of the entire Thamnophilus genus. However, the present study is the first one applied to the genetics of T. ambiguus and T. pelzelni. Here, we used sequences of mtDNA control region, Cytochrome b, and ND2 to quantify the levels of molecular divergence between these two bird species. The three mtDNA regions have been shown to be useful for the genetic analysis of very closely related species. Since T. ambiguus and T. pelzelni are very alike, and only recently the use of morphological and vocal markers allowed their classification as different species, we believe that the use of molecular markers would shed new light on this subject.

\section{Material and Methods}

\subsection{Taxon sampling and DNA extraction}

Individuals of Thamnophilus ambiguus $(\mathrm{n}=22)$ were sampled in Minas Gerais $(n=16)$, Bahia $(n=4)$, and Espírito Santo $(n=2)$ States, in Brazil. Within Minas Gerais, the sampling regions are distant from each other up to $400 \mathrm{~km}$, and most of them represent patches of the Atlantic Forest biome, although maintaining differences concerning altitude, climate, and vegetation. Individuals of $T$. pelzelni $(\mathrm{n}=21)$ were sampled in Minas Gerais $(\mathrm{n}=9)$, São Paulo $(\mathrm{n}=1)$, Goiás $(\mathrm{n}=8)$, Tocantins $(n=1)$, and Mato Grosso $(n=2)$ States, in Brazil. The approximate locations of the sampling areas, as well as the species' geographic distribution and the number of individuals sampled per population, are presented in Figure 1.

Field work was conducted between 2001 and 2006 and samples were collected from birds that were mostly mist-netted and released, although some were gunshot (blood and liver were used for DNA extraction, respectively). Most samples were classified in the field as Thamnophilus punctatus and, only after genetic analyses and comparisons of their haplotypes with the ones obtained for voucher specimens, they were assigned to T. ambiguus or T. pelzelni on the basis of the clades supported by phylogenetic reconstructions. Therefore, birds that grouped with birds from $T$. ambiguus type locality (populations 11, 18, and 19; Figure 1) were classified as T. ambiguus; birds that grouped with birds from T. pelzelni type locality (populations 1, 2, 7, and 8; Figure 1) were classified as T. pelzelni. Samples were preserved in $70 \%$ ethanol solution that was kept at $-20{ }^{\circ} \mathrm{C}$ in the laboratory until DNA extraction based on a phenol-chloroform protocol (Sambrook et al., 1989). DNA concentration was estimated through visual evaluation of the band resulting from electrophoresis of $5 \mu \mathrm{L}$ 
of DNA in $0.8 \%$ agarose gels stained with ethidium bromide. DNA samples were stored at the DNA Bank of the Laboratório de Biodiversidade e Evolução Molecular (LBEM, ICB / UFMG, Belo Horizonte, MG, Brazil). Reference numbers of individual's DNA as well as their sampling localities, their mitochondrial haplotypes, and their field or voucher numbers are available at Table 1 .

In total, we sequenced the DNA of 46 birds (22 T. ambiguus, $21 \mathrm{~T}$. pelzelni, and three individuals that were included as outgroups: one T. stictocephalus Pelzeln, 1868, another split from the T. punctatus complex, and two T. caerulescens Vieillot, 1816) at three mitochondrial regions comprising 2,386 base pairs (bp).

\subsection{DNA amplification and sequencing}

The entire mtDNA control region $(\sim 1,200$ bp) was amplified using primers L16087 (5, TGGTCTTGTAAACCARARACTGAAG 3') and H16137 (5' AAAATRYCAGCTTTGGGAGTTG 3'), with slight modifications of the primers designed by MD. Sorenson (personal communication). To sequence this region (566 bp), we also used internal primers designed in our laboratory: DL6 (5' ACCACATCAGACATACTATGTA 3') and DH2 (5' CTGACCGAGGAACCAGAGGCGCA 3'). The entire Cytochrome b gene (Cytb, 1,100 bp) was amplified using primers L14841 (Kocher et al., 1989) and H16065 (Lougheed et al., 2000), and sequenced (837 bp) with these two primers plus two internal primers: CytbINTF and CytbINTR (Brumfield and Edwards, 2007). The NADH dehydrogenase subu- nit 2 gene (ND2, 1,100 bp) was amplified with primers L5216 (5' GGCCCATACCCCGRAAATG 3') and H6313 (5' ACTCTTRTTTAAGGCTTTGAAGGC 3') from MD. Sorenson, and sequenced (982 bp) with these two primers plus the internal primer H5766 (Brumfield and Edwards, 2007). The control region was not sequenced for two T. pelzelni individuals.

Amplification reactions of all mtDNA regions were conducted in a final volume of $12.5 \mu \mathrm{L}$ using $10-40 \mathrm{ng}$ of DNA, 1x Tris-KCl PCR buffer, $1.5 \mathrm{mM} \mathrm{MgCl}_{2}, 200 \mu \mathrm{M}$ dNTPs, $0.5 \mu \mathrm{M}$ primers, and $1 \mathrm{U}$ of Taq DNA polymerase (Phoneutria, Brazil). Amplifications were done under the following conditions: initial step of denaturation of $94{ }^{\circ} \mathrm{C}$ for 2 minutes, followed by 35 cycles of $94{ }^{\circ} \mathrm{C}$ for 30 seconds, $53-60-65{ }^{\circ} \mathrm{C}$ (respectively for Cytb, ND2, and control region) for 45 seconds and $72{ }^{\circ} \mathrm{C}$ for 2 minutes, with a final extension of $72{ }^{\circ} \mathrm{C}$ for 10 minutes. After amplification, $\mathrm{PCR}$ products were run in $1 \%$ agarose gels stained with ethidium bromide. Negative controls (PCR reactions with no template DNA) were used in all amplification runs. Only products with a single, well-defined, robust band were used in the sequencing reactions. Before sequencing, PCR products were precipitated using the polyethylene glycol (20\% PEG 8000 and $2.5 \mathrm{M}$ $\mathrm{NaCl})$ to remove unincorporated nucleotides and short DNA fragments, including single strands.

Sequencing reactions were conducted in a final volume of $10 \mu \mathrm{L}$ containing: $2-4 \mu \mathrm{L}$ of purified PCR product, $1-3 \mu \mathrm{L}$ of ultrapure water, $1 \mu \mathrm{L}$ of primer $(0.5 \mu \mathrm{M}$

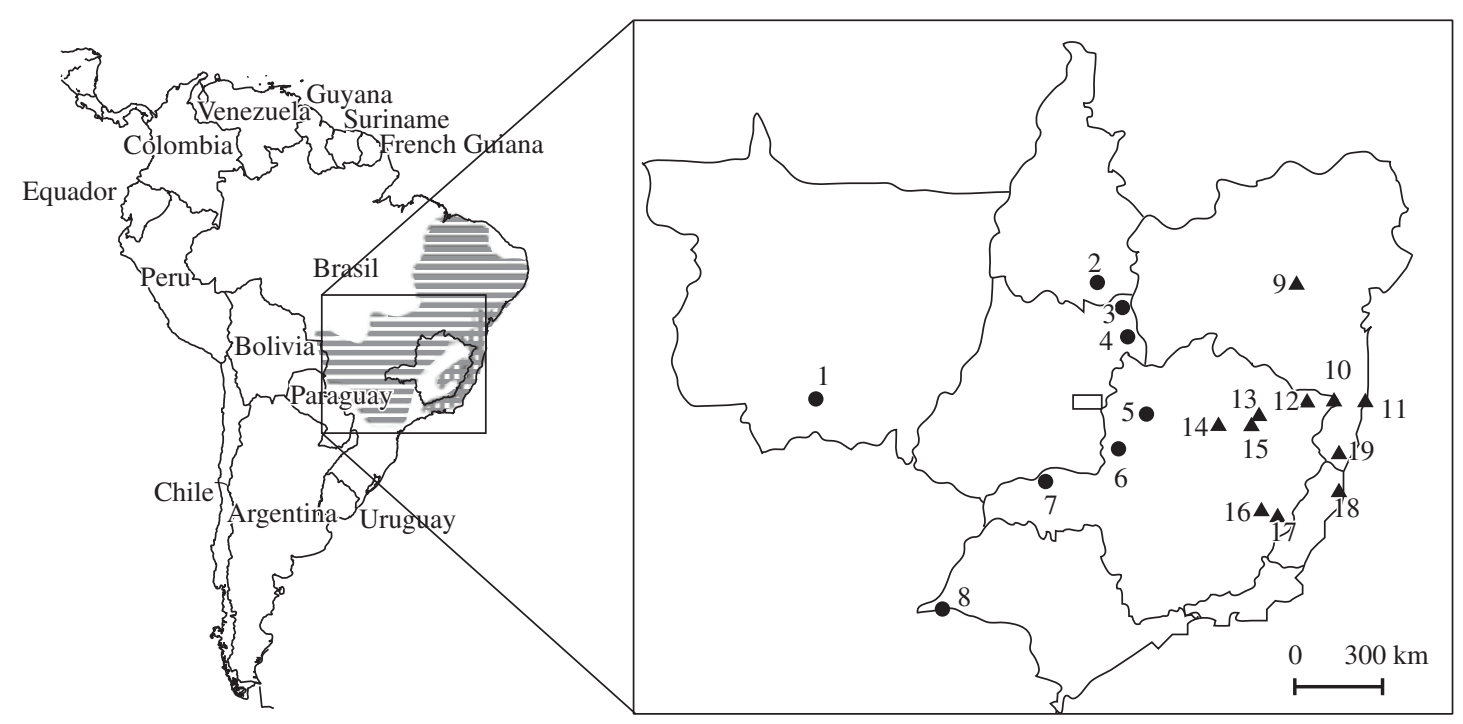

Figure 1. Proposed geographic distribution for T. ambiguus (vertical hatching) and T. pelzelni (horizontal hatching) (Isler et al., 1997) and approximate location of the sampling areas in the present study. Triangle and circles represent, respectively, areas where T. ambiguus and T. pelzelni (classified according to the phylogenetic analysis) were sampled. $1=$ Nossa Senhora do Livramento $(\mathrm{n}=2), 2$ = Paranã $(\mathrm{n}=1), 3$ = São Domingos $(\mathrm{n}=7), 4$ = Alvorada $(\mathrm{n}=1), 5$ = Brasilândia de Minas $(\mathrm{n}=7), 6=$ Vazante $(\mathrm{n}=1), 7=$ Canápolis $(\mathrm{n}=2), 8=$ Teodoro Sampaio $(\mathrm{n}=1), 9=$ Andaraí $(\mathrm{n}=1), 10=$ Salto da Divisa $(\mathrm{n}=3), 11$ = Porto Seguro $(\mathrm{n}=1), 12$ = Jequitinhonha $(\mathrm{n}=3), 13$ = José Gonçalves de Minas $(\mathrm{n}=1), 14=$ Bocaiúva $(\mathrm{n}=4)$, $15=$ Leme do Prado $(n=1), 16=$ Marliéria $(n=1), 17=$ Caratinga $(n=2), 18=$ Sooretama $(n=2), 19=$ Mucuri $(n=2)$. 
Table 1. List of the 43 analyzed individuals of Thamnophilus ambiguus and T. pelzelni with their sampling localities, mtDNA haplotypes, and voucher of field ID.

\begin{tabular}{|c|c|c|c|}
\hline DNA number ${ }^{\mathrm{a}}$ & locality & mtDNA haplotype & voucher or field ID \\
\hline B2302 & 1 & Tp01 & DZ5140 \\
\hline B2303 & 1 & $*$ & DZ5141 \\
\hline B1493 & 2 & Тр01 & COMB2648 \\
\hline B1494 & 3 & Тр01 & LM-2 \\
\hline B1496 & 3 & Тр03 & LM-4 \\
\hline B1497 & 3 & Тр03 & LM-5 \\
\hline B1500 & 3 & Тр01 & LM-8 \\
\hline B1502 & 3 & Тр01 & LM-10 \\
\hline B1507 & 3 & Tp01 & LM-15 \\
\hline B1508 & 3 & Tp01 & LM-16 \\
\hline B1510 & 4 & Tp04 & LM-18 \\
\hline B1213 & 5 & Ta16 & G59764 \\
\hline B1147 & 5 & Tp07 & G50106 \\
\hline B1148 & 5 & Tp08 & E51761 \\
\hline B1150 & 5 & Tp07 & G51298 \\
\hline B1156 & 5 & Тp02 & G59743 \\
\hline B1207 & 5 & Тр01 & G51299 \\
\hline B1208 & 5 & Tp01 & G59785 \\
\hline B1419 & 6 & Tp07 & DZ4483 \\
\hline B0544 & 7 & Tp05 & E52082 \\
\hline B1268 & 7 & Тр06 & E51954 \\
\hline $\mathrm{P} 1395 \mathrm{c}$ & 8 & * & E13692 \\
\hline B1413 & 9 & $\mathrm{Ta} 03$ & MMC157 \\
\hline B0555 & 10 & $\mathrm{Ta} 01$ & E32943 \\
\hline B0566 & 10 & $\mathrm{Ta} 01$ & E52032 \\
\hline B0574 & 10 & $\mathrm{Ta} 07$ & E52063 \\
\hline B1411 & 11 & Ta12 & MMC109 \\
\hline B0523 & 12 & $\mathrm{Ta} 01$ & E40636 \\
\hline B0545 & 12 & $\mathrm{Ta} 01$ & VDCLDIR n² $2 \mathrm{~A}$ \\
\hline B0547 & 12 & $\mathrm{Ta} 04$ & VMDIR nº $81 \mathrm{~A}$ \\
\hline B2274 & 13 & Ta05 & F02922 \\
\hline B1151 & 14 & $\mathrm{Ta} 02$ & G59725 \\
\hline B1155 & 14 & Ta13 & E46003 \\
\hline B1214 & 14 & Ta14 & G59772 \\
\hline B1398 & 14 & Ta15 & G59800 \\
\hline B2276 & 15 & Ta06 & F03828 \\
\hline B0576 & 16 & Ta11 & E41155 \\
\hline B0534 & 17 & Ta09 & G47711 \\
\hline B0537 & 17 & Ta10 & G47727 \\
\hline B1403 & 18 & Ta09 & MMC82 \\
\hline B1408 & 18 & Ta09 & MMC98 \\
\hline B2018 & 19 & $\mathrm{Ta} 08$ & F04052 \\
\hline B2020 & 19 & Ta09 & E14563 \\
\hline
\end{tabular}

${ }^{a}$ Number of reference in the DNA Bank of the Laboratório de Biodiversidade e Evolução Molecular (ICB/UFMG, Belo Horizonte, Brazil);

${ }^{\mathrm{b}} \mathrm{See}$ Figure 1 for the name of the localities;

${ }^{\mathrm{C}} \mathrm{DZ}$ for vouchers from the Coleção Ornitológica, Departamento de Zoologia, Universidade Federal de Minas Gerais; COMB for vouchers from the Coleção Marcelo Bagno, Departamento de Zoologia, UNB; P for blood sample from LGEMA, Instituto de Biociências, Universidade de São Paulo; MMC for field ID of the individuals collected by M. Maldonado Coelho; LM for field ID of the individuals collected by $\mathrm{L}$. Leite; the others are ring numbers.

*Not in Figure 2: control region haplotype was not defined, but ND2 and Cytb point to an haplotype that is phylogenetically close to Tp01. 
final concentration), $4 \mu \mathrm{L}$ of sequencing kit (ET DYE Terminator Kit, GE Healthcare). The sequencing program consisted of 35 cycles of $95{ }^{\circ} \mathrm{C}$ for 25 second, $50-55{ }^{\circ} \mathrm{C}$ for 15 second, and $60{ }^{\circ} \mathrm{C}$ for 3 minutes. Sequencing products were precipitated with ammonium acetate and ethanol, dried at room temperature, ressuspended with formamide-EDTA, and run in the MegaBACE 1000 sequencer (GE Healthcare).

\subsection{Avoiding numts}

To avoid the amplification of nuclear sequences of mitochondrial origin, i.e. numts (Sorenson and Quinn, 1998), the following measures were undertaken: i) we amplified sequences longer than 1,000 bp; ii) amplification primers had degenerate sites and/or had annealing sites in tRNA genes; iii) high-resolution polyacrylamide gels were used while establishing the optimum conditions for each primer combination, which allowed us to ensure the presence of a single, strong and well-defined band of the expected size; iv) most part of the consensus sequences was obtained from sequences of different DNA strands (using forward and reverse primers for sequencing), although some high quality portions of the same strand, usually at the edges of the sequence, were also admitted; v) for each individual, at least two different PCR products were used in the sequencing reactions till at least two high quality, independent sequences, could be obtained for each one of the sequencing primers; vi) chromatograms were carefully checked for ambiguities; and vii) Cytb and ND2 sequences were aligned and compared with others available at the GenBank, including a sequence of Gallus gallus (Desjardins and Morais, 1990), a procedure that did not reveal any start, stop, or nonsense codons, as well as alignment gaps.

\subsection{Sequence alignment and statistical analyses}

Consensus sequences were obtained and checked through the programs Phred v. 0.20425 (Ewing and Green, 1998), Phrap v. 0.990319 (http://www.phrap. org), and Consed 12.0 (Gordon et al., 1998). Alignments were done using Clustal X (Thompson et al., 1997), with manual edition whenever it was necessary. Sequences are deposited in GenBank under the access numbers EU295759-EU295894

Nucleotide diversity measures (mean number of differences and the mean uncorrected pairwise distance, i.e. p-distance) among sequences were obtained through the program MEGA 3.1 (Kumar et al., 2001). MEGA 3.1 was also used to construct a neighbor-joining tree using Kimura 2 parameters substitution model (K2p), and also maximum parsimony trees for different datasets (individual mtDNA regions and combined data). Sequences were then grouped as T. ambiguus or T. pelzelni according to clades definition, and levels of sequence divergence within and among them, and with outgroup species were estimated. Furthermore, a Maximum-likelihood (ML) analysis was performed through PAUP*, version $4.0 \mathrm{~b} 10$ (Swofford, 1998), after using MODELTEST (Posada and Crandall, 1998) to select the best-fit model of molecular evolution for the complete dataset $(2,386 \mathrm{bp})$ that included 27 terminals (three outgroups and 24 T. ambiguus plus $T$. pelzelni unique haplotypes). The ML analysis was performed using heuristic tree search, TBR branch swapping with 10 random-addition replicates. For phylogenetic reconstructions, 1,000 bootstrap replicates were performed to determine the robustness of the trees and majority-rule consensus trees were generated.

\section{Results}

We analyzed a total of 2,386 bp of mtDNA comprising parts of the control region (partial sequences of domains I and II), Cytb and ND2 genes. We could not find any suggestive evidence of the presence of numts. PCR reactions were performed under stringent conditions and, for all consensus sequences checked through Consed, we have not observed any instance of high quality discrepancies that could be also the result of numts interference.

Among the 22 analyzed individuals of T. ambiguus, we identified 11 control region haplotypes (12 variable sites), 12 Cytb haplotypes (17 variable sites), and 13 ND2 haplotypes (15 variable sites). Among the analyzed individuals of T. pelzelni, we identified nine control region haplotypes (11 variable sites for 19 individuals), five Cytb haplotypes (ten variable sites for 21 individuals), and eight ND2 haplotypes (eight variable sites for 21 individuals).

Most of the sequence variation was related to single base substitutions, mainly transitions, as expected for mitochondrial DNA. Comparing base composition of T. ambiguus and T. pelzelni individuals, we found that it was in accordance with what is expected for vertebrate mitochondrial DNA, with low levels of guanine in the L strand. Also, thymine was less frequent in the $3^{\text {rd }}$ codon position, as is typical of avian Cytb (Kocher et al. 1989). A single indel was identified in the control region and it was found among sequences within T. ambiguus. Most of the variable sites in the control region were located before position 300 of the alignment, i.e. in the hypervariable domain I. Besides, for both Cytb and ND2, most mutations $(>70 \%)$ occurred in the $3^{\text {rd }}$ codon position that presented low guanine content $(<3 \%)$ for both genes. The proportion of informative sites was higher than $80 \%$ for the three mtDNA regions, although it was always higher for Cytb. Some $1^{\text {st }}$ or $2^{\text {nd }}$ codon changes lead to amino acid substitutions, both within and among T. ambiguus and T. pelzelni, in the Cytb and ND2 sequences. The total number of amino acid substitutions, considering both genes and both species, was 16 . This number increases to 26 if $T$. stictocephalus is included, and to 36 if $T$. caerulescens is compared to those three splits from the T. punctatus complex analyzed here. Nucleotide substitutions identified between T. ambiguus and T. pelzelni are presented in Table 2. Most of them were found in the two coding regions, while few fixed differences were found in the control region, indicating, as expected, the high level of intra-group variation detected in this non- 
Table 2. Fixed differences in the control region, ND2, and Cytochrome b between Thamnophilus ambiguus and T. pelzelni. Numbers represent the alignment positions according to the Gallus gallus complete mitochondrial sequence (Desjardins and Morais, 1990).

\begin{tabular}{lccc}
\hline \multicolumn{1}{c}{ Species } & CR & ND2 & Cytb \\
\hline & & & 111111111111111111111111111111 \\
& & & \\
& & & \\
& 94123535555555555555555556666666 & 45555555555555555555555555555555 \\
& 22333445556666677889990001122 & 90000011111122333344445556666678 \\
T. ambiguus & TGATACGA & CTCTCTCACATCTCCCATTGTTAGTGTCT & GCTAGCGATCTGCCCCCTATTCACCGTTTTGT \\
T. pelzelni & CAGCCTTT & TCTCACTGTGCTCTTTGCCACCCACACAC & ATCGATAGCTCATTTTTCGCCTGTTACCCCAC \\
\hline
\end{tabular}

coding region.

The number of differences and the p-distance among control region, ND2, and Cytb haplotypes within species as well as between T. ambiguus and T. pelzelni, are presented in Table 3. Although extensive variation was observed among haplotypes within the two taxa, especially for the control region, it is evident that there was considerable divergence between $T$. ambiguus and T. pelzelni haplotypes for the three mitochondrial regions, a difference that was usually $10 \mathrm{x}$ higher than the observed within taxa. The mean pairwise distance between sequences of T. ambiguus and T. pelzelni was $2.7 \%$ for control region, $3.6 \%$ for $\mathrm{ND} 2$, and $4.9 \%$ for Cytb, values that, when compared to the literature (see Discussion) seem to be high enough to corroborate the species distinctiveness of these two taxa. Considering the three mtDNA regions, the mean pairwise distance between the two taxa was $3.8 \%$, while it was $0.5 \%$ within $T$. ambiguus and $0.3 \%$ within T. pelzelni. Comparisons of pairwise distances among T. caerulescens, T. stictocephalus and the two taxa that we are focusing in this study, showed higher levels of divergence (Table 4 and Table 5), as expected based on their higher distinction considering morphological or vocal characterizations.

The ML reconstruction was performed with a HKY $+\mathrm{G}$ model with a Ti/Tv ratio of 8.83 and a gamma distribution shape parameter of 0.2112 . Two main clades were recovered, showing a clear separation between T. ambiguus and T. pelzelni (Figure 2). These two clades were also revealed with high bootstrap support, in any of the other neighbor-joining or MP reconstructions (trees not shown). Within the two main clades, some groups were well supported no matter which mtDNA sequences we included in the reconstruction. That was the case of the two T. pelzelni from Canápolis (population 7; Figure 1) that always clustered together (Tp05 and Tp06). Within T. ambiguus, for all tree reconstructions, we had a clear distinction between birds from south Bahia, Espirito Santo, and SE Minas Gerais (Ta08-Ta16), from birds from north Minas Gerais and central Bahia (Ta01-Ta07). Thamnophilus ambiguus from Bocaiúva (population 14; Figure 1) always clustered together with high bootstrap support (Ta13-Ta15),

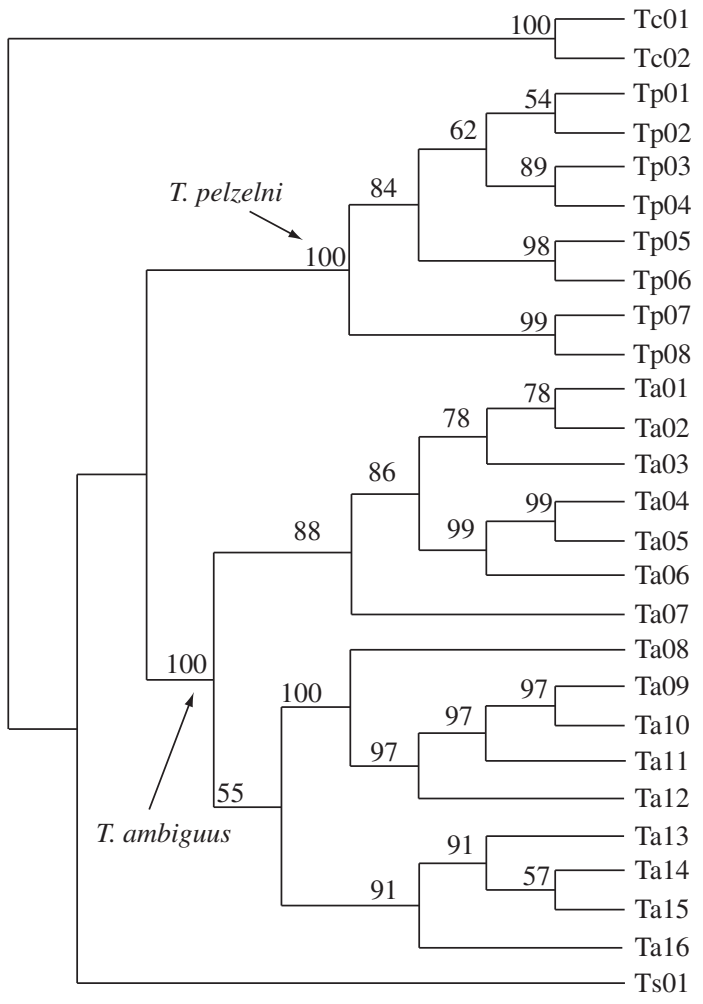

Figure 2. Strict consensus tree of maximum likelihood for the three mitochondrial regions using 27 unique haplotypes of T. ambiguus (Ta) and T. pelzelni (Tp). Nodal supports above branches are based on 1,000 bootstraps. Thamnophilus caerulescens (Tc) and T. stictocephalus (Ts) were used as outgroups. See Table 1 for sampling localities where haplotypes were found.

although a single bird (B1151, Ta02) grouped with a different T. ambiguus lineage. Furthermore, Brasilândia de Minas (population 5; Figure 1) was the single location where we found representatives of the two taxa; although most birds from this locality grouped with $T$. pelzelni (Tp01, Tp02, and Tp08), one exception grouped with T. ambiguus (B1213, Ta16), always together with birds 
Table 3. Mean number of differences \pm SE and mean pairwise distance \pm SE (p-distance) among control region, ND2, and Cytb haplotypes within Thamnophilus ambiguus and T. pelzelni and between both species.

\begin{tabular}{lccc}
\hline \multicolumn{1}{c}{ mtDNA region } & $\begin{array}{c}\text { Within } \\
\text { T. ambiguus }\end{array}$ & $\begin{array}{c}\text { Within } \\
\text { T. pelzelni }\end{array}$ & $\begin{array}{c}\text { T. ambiguus } \mathbf{x} \\
\text { T. pelzelni }\end{array}$ \\
\hline $\mathbf{3}$ mtDNA regions $\mathbf{( 2 , 3 8 5}$ bp) & & & \\
Number of differences & $12.8 \pm 2.2$ & $6.9 \pm 1.5$ & $91.3 \pm 9.0$ \\
p-distance & $0.005 \pm 0.001$ & $0.003 \pm 0.001$ & $0.038 \pm 0.004$ \\
Control region (566 bp) & & & \\
$\quad$ Number of differences & $4.0 \pm 1.3$ & $2.9 \pm 0.9$ & $15.0 \pm 3.3$ \\
p-distance & $0.007 \pm 0.002$ & $0.005 \pm 0.002$ & $0.027 \pm 0.006$ \\
ND2 $(\mathbf{9 8 2}$ bp) & & & \\
Number of differences & $4.1 \pm 1.2$ & $1.3 \pm 0.5$ & $35.1 \pm 5.1$ \\
p-distance & $0.004 \pm 0.001$ & $0.001 \pm 0.001$ & $0.036 \pm 0.005$ \\
Cytb $(\mathbf{8 3 7}$ bp) & & & \\
Number of differences & $4.6 \pm 1.3$ & $2.6 \pm 0.9$ & $41.2 \pm 5.9$ \\
p-distance & $0.005 \pm 0.002$ & $0.003 \pm 0.001$ & $0.049 \pm 0.007$ \\
\hline
\end{tabular}

Table 4. Mean pairwise distance \pm SE (p-distance) among the three mtDNA regions (2,385 bp; lower matrix) and control region (566 bp; upper matrix) haplotypes of Thamnophilus caerulescens (Tca), T. stictocephalus (Tst), T. ambiguus (Tam), and T. pelzelni (Tpe).

\begin{tabular}{lcccc}
\hline & Tca & Tst & Tam & Tpe \\
\hline Tca & - & $0.038 \pm 0.007$ & $0.070 \pm 0.010$ & $0.059 \pm 0.009$ \\
Tst & $0.082 \pm 0.005$ & - & $0.064 \pm 0.010$ & $0.058 \pm 0.009$ \\
Tam & $0.076 \pm 0.005$ & $0.082 \pm 0.005$ & - & $0.027 \pm 0.006$ \\
Tpe & $0.068 \pm 0.005$ & $0.082 \pm 0.005$ & $0.038 \pm 0.004$ & - \\
\hline
\end{tabular}

Table 5. Mean pairwise distance \pm SE (p-distance) among ND2 (982 bp; lower matrix) and Cytb (837 bp; upper matrix) haplotypes of Thamnophilus caerulescens (Tca), T. stictocephalus (Tst), T. ambiguus (Tam), and T. pelzelni (Tpe).

\begin{tabular}{lcccc}
\hline & Tca & Tst & Tam & Tpe \\
\hline Tca & - & $0.095 \pm 0.010$ & $0.079 \pm 0.009$ & $0.069 \pm 0.008$ \\
Tst & $0.097 \pm 0.010$ & - & $0.089 \pm 0.010$ & $0.090 \pm 0.010$ \\
Tam & $0.076 \pm 0.008$ & $0.086 \pm 0.009$ & - & $0.049 \pm 0.007$ \\
Tpe & $0.072 \pm 0.008$ & $0.090 \pm 0.009$ & $0.036 \pm 0.005$ & - \\
\hline
\end{tabular}

from Bocaiúva. Unfortunately, vouchers from these samples were not obtained, although DNA is available for future reference (Table 1).

\section{Discussion}

Many recent studies of mtDNA in birds have allowed the quantification of sequence divergence among distinct taxa at different levels between populations, subspecies, species, genus, families, and higher taxa. Sequences of mtDNA control region are mainly used to investigate the relationships within species or between closely related species (e.g. Omland et al., 2000; Kvist et al., 2001; Rhymer et al., 2001). Recently, Ruokonen and Kvist (2002) analyzed bird control region sequences obtained in the GenBank and estimated a broad varia- tion on levels of divergence in pairwise comparisons of species within genus, with values ranging from $0.54 \%$ to $17.30 \%$, although most values were above $2.72 \%$. The p-distances found in the present study among control region haplotypes within the two taxa, as well as between T. ambiguus and T. pelzelni, are both falling within that range. However, the value observed among haplotypes of different taxa is more than $7 x$ higher than that observed within T. ambiguus, and more than 10x higher than the observed within T. pelzelni. Thus, we conclude that the divergence found among control region haplotypes of the two taxa is high enough to support the species status of T. ambiguus and T. pelzelni. This statement could be better sustained by examples of "good", well defined species exhibiting similar levels of diver- 
gence in the mtDNA control region. We found a similar p-distance among control region haplotypes of two other species of the Thamnophilus genus: $3 \%$ of divergence between $T$. palliatus Lichtenstein, 1823 and T. doliatus Linnaeus, 1764 (Lacerda, 2004). Although T. doliatus and $T$. palliatus are closely related species, sharing a similar plumage pattern, they are well defined species based both on morphological (Zimmer and Isler, 2003) and vocal characters (Isler et al., 1998). An even lower divergence value $(1.9 \%)$ was found among control region haplotypes of two well defined and closely related species of the Aratinga genus: A. auricapillus Kuhl, 1820 and A. jandaya Gmelin, 1788 (Ribas and Miyaki, 2004).

In the present study, the genetic distances computed for the control region were lower than the ones computed for Cytb or ND2, a fact that we believe to be related to the high saturation levels that are usually present at the fast evolution parts of the control region (such as domain I). That difference between coding and non-coding mtDNA regions was already detected by other authors that associated that result with the fact that the central domain of the control region may have a slower rate of evolution than mitochondrial genes (Zink et al., 1999). Although both fast- and slow-evolution parts of the control region were used in this study, we believe that saturation may be a problem for interespecific comparisons and, consequently, control region divergence values need to be considered with care, since they may be an underestimate of the real divergence between species.

The Cytochrome b and ND2 sequences allowed us to observe more clearly the molecular differentiation of T. ambiguus and T. pelzelni. For these two mtDNA genes, we observed, respectively, 4.9 and $3.6 \%$ of divergence between these two typical antbirds. Although the divergence found for Cytb is the lowest value observed among nine Thamnophilidae species that our group analyzed (Lacerda, 2004), the comparisons with data available in the literature support the species status of T. ambiguus and T. pelzelni. García-Moreno and Silva (1997), for example, found <2\% of divergence among Cytb sequences of two species of Lepidocolaptes. Similar values were observed between two Aratinga species (Ribas and Miyaki, 2004). According to multiple species' data reviewed by Johns and Avise (1998), several congeneric bird species present Cytb interspecies divergence between 2 and 10\%. Finally, divergences recently found between four pairs of sister species of the Thamnophilus genus (Brumfield and Edwards, 2007) can be directly compared to what we found in the present study for T. ambiguus and T. pelzelni. The pair T. nigrocinereus Sclater, 1855 and T. cryptoleucus Menegaux and Hellmayr, 1906 and the pair T. nigriceps and T. praecox showed, respectively, 1.3 and $3.3 \%$ of divergence for Cytb and 1.1 and $4.5 \%$ of divergence for ND2, corroborating previous sister relationship and suggesting a recent divergence. On the other hand, a sister relationship between T. aethiops Sclater, 1858 and T. aroyae was revealed for the first time, with a divergence of 5.8 and $5.1 \%$ between these two spe- cies, for Cytb and ND2, respectively. Also, two representatives of the former Thamnophilus punctatus complex ( $T$. punctatus and T. stictocephalus) were shown to be weakly differentiated, exhibiting 5.1 and $2.9 \%$ of sequence divergence for Cytb and ND2, respectively. These numbers clearly suggest a sister relationship between $T$. ambiguus and T. pelzelni.

According to Isler et al. (1997), Thamnophilus ambiguus is expected to be found at the coastal zone of Brazil and inland in the eastern Minas Gerais, in elevations below $400 \mathrm{~m}$. That proposed geographic distribution is based mainly in the analysis of vocal markers of birds from several different localities, but it is important to notice that morphological analyses were not performed in any bird from Minas Gerais (see Appendix 1, specimens examined, in Isler et al. 1997). Therefore, we conclude that a precise definition of the localities where T. ambiguus or T. pelzelni can be found remains to be determined. In the present study, some specimens sampled in the north of Minas Gerais (populations 10, 12, 13, 14, and 15), as well as inland in Bahia (population 9), strongly grouped, in the phylogenetic reconstructions, with birds from $T$. ambiguus type localities. We also found that two clades can be distinguished within T. ambiguus and that population 5 holds birds showing mtDNA haplotypes from both T. ambiguus and T. pelzelni. Together, those results show that more detailed morphological and phylogeographic analyses should be conducted in these species.

Based on a molecular clock of $2 \%$ of sequence divergence per million years, frequently found for avian Cytb comparisons (Tarr and Fleischer, 1993; Paxinos et al., 2002), we can estimate the time since T. ambiguus and T. pelzelni diverged from their common ancestor as around 2.5 MYA. However, using recently published evolution rates of $1.6 \%$ for Cytb and $4.0 \%$ for ND2 (Brumfield and Edwards, 2007), we obtained divergence times between those two species occurring around 3 and 0.9 MYA, respectively. Although this is a rough estimation (Lovette, 2004), it allows us to establish a temporal framework for the initial separation between T. ambiguus and T. pelzelni, which might have occurred in the end of the Pliocene. It would be interesting to determine the divergence levels among all species within the $T$. punctatus complex, in order to verify factors that may be involved in their genetic differentiation. Isler et al. (1997) suggest that T. atrinucha had been separated first by the Andes or changes in the sea level, while other taxa found east of the Andes, like the ones we are considering in this study, differentiated later. This result seems to be in accordance with Brumfield and Edwards (2007) that found a basal split between the T. atrinucha clade (that holds two other trans-Andean species) and a cis-Andean clade. Furthermore, those authors estimated that a clade exclusively containing lowland-restricted species (including T. punctatus and T. stictocephalus, two former "T. punctatus complex") diverged around 3.6 and 1.6 MYA (based on Cytb and ND2, respective- 
ly) from its sister clade that holds $T$. caerulescens and other lowland-to-highland or highland-restricted species. Therefore, diversification within the first clade, which would probably include all cis-Andean species formerly in the "T. punctatus" complex, likely occurred just after the separation between lowland-species from the montane $T$. caerulescens clade.

Finally, the lack of clinal intermediacy between T. ambiguus and T. pelzelni (Naumburg, 1937; Isler et al., 1997) reinforces their separate species status and suggests that they do not hybridize. Hybridization is a very common event for birds, even for species from different genera (Marini and Hackett, 2002). Therefore, a detailed sampling in areas where T. ambiguus and T. pelzelni are likely to come in contact (such as population 5 and other areas in Minas Gerais or Bahia), followed by molecular studies (including nuclear as well as mitochondrial markers), would be necessary to verify if they are really not hybridizing. In terms of conservation practice, the endemicity of T. ambiguus to the Brazilian Atlantic forest is extremely relevant. However, the potential occurrence of hybrids should be further investigated. In the near future, it may also be possible to detect changes in the mating habits or geographical distribution of the species related to habitat destruction/fragmentation. Besides, conservation projects need to consider ongoing processes to better direct financial resources as well as to determine the evolutionary potential of the populations.

Acknowledgments - Owners/administrators have allowed our study in their private properties/conservation units. IBAMA (Environment Agency of Brazil) gave banding/collecting authorizations. We thank Leonardo Lopes, Alexandre Fernandes, Lucas Carrara, Lemuel Leite, Marcelo Vasconcelos, Marcos Maldonado, and other ones for help collecting and identifying birds. We are grateful to managers of the ornithological collections from USP, UnB, and UFMG. We thank the laboratory staff for helping with molecular biology techniques and genetic analysis. DRL, MÂM and FRS are supported by CNPq, Brazil. This project was performed with grants from FAPEMIG and CNPq, Brazil. The samples were collected with licenses of IBAMA, Brazil, and are deposited in the DB-LBEM - ICB/ UFMG registered in MMA/CGEN (Brazil) under protocol \# 02000.002032/2003-26 published in 14 January 2004.

\section{References}

BRUMFIELD, RT. and EDWARDS, SV., 2007. Evolution into and out of the Andes: a Bayesian analysis of the historical diversification in Thamnophilus antshrikes. Evolution, vol. 61, p. 346-367.

DESJARDINS, P. and MORAIS, R., 1990. Sequence and gene organization of the chicken mitochondrial genome: a novel gene order in higher vertebrates. J. Molec. Biol., vol. 212, p. 599-634.

EWING, B. and GREEN, P., 1998. Basecalling of automated sequencer traces using Phred II: error probabilities. Genome Res., vol. 8, p. 186-194.

GARCÍA-MORENO, J. and SILVA, JM., 1997. An interplay between forest and non-forest South American avifaunas suggested by a phylogeny of Lepidocolaptes woodcreepers
(Dendrocolaptinae). Stud. Neotrop. Fauna Envir., vol. 32, p. 164-173.

GORDON, D., ABAJIAN, C. and GREEN, P., 1998. Consed: a graphical tool for sequence finishing. Genome Res., vol. 8, p. 195-202.

ISLER, ML., ISLER, PR. and WHITNEY, BM., 1997. Biogeography and systematics of the Thamnophilus punctatus (Thamnophilidae) complex. Ornit. Monogr., vol. 48 , p. $355-381$.

ISLER, ML., ISLER, PR. and WHITNEY, BM., 1998. Use of vocalizations to establish species limits in antbirds (Passeriformes: Thamnophilidae). Auk, vol. 115, p. 577-590.

JOHNS, GC. and AVISE, JC., 1998. A comparative summary of genetic distances in the vertebrates from the mitochondrial Cytochrome b gene. Mol. Biol. Evol., vol. 15, p. 481-1490.

KOCHER, TD., THOMAS, WK., MEYER, A., EDWARDS, S., PÄÄBO, S., VILLABLANCA, FX. and WILSON, AC., 1989. Dynamics of mitochondrial DNA evolution in animals: amplification and sequencing with conserved primers. Proc. Natl. Acad. Sci. USA, vol. 86, p. 6196-6200.

KUMAR, S., TAMURA, K. and NEI, M., 2001. MEGA: Molecular Evolutionary Genetics Analysis. Pennsylvania, The Pennsylvania State University.

KVIST, L., MARTENS, J., AHOLA, A. and ORELL, M., 2001. Phylogeography of a Palaearctic sedentary passerine, the willow tit (Parus montanus). J. Evol. Biol. vol. 14, p. 930-941.

LACERDA, DR., 2004. Filogeografia comparada e filogenia de espécies de Thamnophilidae (Aves:Passeriformes) de Mata Atlântica de Minas Gerais. 89p. (Tese de Doutorado) - UFMG, Belo Horizonte, MG, Brazil.

LOUGHEED, SC., FREELAND, JR., HANDFORD, P. and BOAG, PT., 2000. A molecular phylogeny of warbling-fiches (Poospiza): paraphyly in a Neotropical Emberizid genus. Mol. Phylogenet. Evol., vol. 17, p. 367-378.

LOVETTE, IJ., 2004. Mitochondrial dating and support for the "2\% rule" in birds. Auk, vol. 121,v p. 1-6.

MARINI, MA. and HACKETT, S., 2002. A multifaceted approach to the characterization of an intergeneric hybrid manakin (Pipridae) from Brazil. Auk, vol. 119, p. 1114-1120.

MYERS, N., MITTERMEIER, RA., MITTERMEIER, CG., FONSECA, GAB. and KENT, J., 2000. Biodiversity hotsposts for conservation priorities. Nature, vol. 403, p. 853-858.

NAUMBURG, EMB., 1937. Studies of birds from eastern Brazil and Paraguay, based on a collection by Emil Kaempfer. Bull. Am. Mus. Nat. His., vol. 74, p. 139-205.

OMLAND, KE., TARR, CL., BOARMAN, WI., MARZLUFF, JM. and FLEISCHER, RC., 2000. Cryptic genetic variation and paraphyly in ravens. Proc. R. Soc. Lond. B, vol. 267, p. $2475-2482$.

PAXINOS, EE., JAMES, HF., OLSON, SL., SORENSON, MD., JACKSON, J. and FLEISCHER, RC., 2002. MtDNA from fossils reveals a radiation of Hawaiian geese recently derived from the Canada Goose (Brantha canadensis). Proc. Natl. Acad. Sci. USA, vol. 99, p. 1399-1404.

POSADA, D. and CRANDALL, KA., 1998. Modeltest: testing the model of DNA substitution. Bioinformatics, vol. 14, p. $817-818$. 
RHYMER, JM., FAIN, MG., AUSTIN, JE., JOHNSON, DH. and KRAJEWSKI, C., 2001. Mitochondrial phylogeography, subspecific taxonomy, and conservation genetics of sandhill cranes (Grus canadensis; Aves: Gruidae). Conserv. Genet., vol. 2, p. 203-218.

RIBAS, CC. and MIYAKI, CY., 2004. Molecular systematics in Aratinga parakeets: species limits and historical biogeography in the 'solstitialis' group, and the systematic position of Nandayus nenday. Mol. Phylogenet. Evol., vol. 30, p. 663-675.

RUOKONEN, M. and KVIST, L., 2002. Structure and evolution of the avian mitochondrial control region. Mol. Phylogenet. Evol., vol. 23, p. 422-432.

SAMBROOK, J., FRITSCH, EF. and MANIATIS, T., 1989. Molecular cloning: a laboratory manual. New York, CSHL Press.

SORENSON, MD. and QUINN, TW., 1998. Numts: a challenge for avian systematics and population biology. Auk, vol. 115, p. 214-221.

STOTZ, DF., FITZPATRICK, JW., PARKER III, TA. and MOSKOVITS, DK., 1996. Neotropical birds: ecology and conservation. Chicago, University of Chicago Press. 502p.
SWOFFORD, DL., 1998. PAUP*: Phylogenetic analysis using parsimony (* and other methods). Version 4.0b10. Massachusetts, Sinauer Associates. 128p.

TARR, CL. and FLEISCHER, RC., 1993. Mitochondrial DNA variation and evolutionary relationships in the Amakihi complex. Auk, vol. 110, p. 825-831.

THOMPSON, JD., GIBSON, TJ., PLEWNIAK, F., JEANMOUGIN., F. and HIGGINS, DG., 1997. The ClustalX windows interface: flexible strategies for multiple sequence alignment aided by quality analysis tools. Nucleic Acids Res., vol. 24 , p. 4876-4882.

ZIMMER, JT., 1933. Studies of Peruvian birds. No. 10. The Formicarius genus Thamnophilus. Part 2. Amer. Mus. Novit., vol. 647 , p. 1-27.

ZIMMER, KJ. and ISLER, ML., 2003. Family Thamnophilidae. In DEL HOYO, J., ELLIOT, A. and CHRISTIE, DA. (eds.). Handbook of the birds of the world: broadbills to tapaculos. v. 8. Barcelona, Lynx Edicions, p. 448-681.

ZINK, RM., DITTMANN, DL., LICKA, J. and BLACKWELLRAGO, RC., 1999. Evolutionary patterns of morphometrics, allozymes, and mitochondrial DNA in Thrashers (genus Toxostoma). Auk, vol. 116, p. 1021-1038. 